\title{
Flooding in Poland in 2010 as a Exemplification of Efforts of the Polish Social Work Services in Case of Disaster
}

\author{
Sławomir Wilk, PhD \\ Institute of Sociology, Rzeszów University \\ wilk@ur.edu.pl \\ Jarosław Kinal, M.A. \\ Institute of Sociology, Rzeszów University \\ jaroslawkinal@gmail.com
}

Doi:10.5901/mjss.2014.v5n13p315

\begin{abstract}
Flooding is one of the most common natural disasters. People have dealt with its occurrence and consequences for centuries. It is difficult to predict, occur unexpectedly and proceed with extreme rapidity causing destruction on a massive scale. The unprecedented flooding that hit Poland in 1997 and 2010 had disastrous consequences for the environment, population, infrastructure and economy. Natural disasters, such as flooding in 2010 constitute also a serious test for society and its organization - both administrative structures and specialized services as well as informal social ties, norms and values. The article describes how the polish citizens dealt with the flood of 2010 and after its termination, including support received from family, neighbors and social institutions. The article will describe government statistics and the results of qualitative research conducted among emergency responders (25 individual in - depth interview), the victims (25 individual in - depth interview) and quantitative research 500 questionnaires.
\end{abstract}

Keywords: flooding in Poland, disaster-related research, sociology of disasters, social problems

\section{Introduction}

In the world there has been a growth in various natural disasters made by natural and mankind .(Lam, 2007-Lerner) Flooding is one of the most common natural disasters and belongs to the category of phenomena which we can't prevent. Emerging countries in the process of evolution took over more and more responsibility for the development of citizens. Therefore, the main task of public administration and its specialized units is to ensure the safety of citizens both before, during and after the occurrence of emergencies such as natural disasters.

Floods are the things that are difficult to predict, occur unexpectedly and cause large consequences for the environment, infrastructure and society. The flood, which occurred in May and June 2010 took the form of unprecedented element, and was one of the biggest in the Polish history. The article describes how the public administration or its specialized agencies provided counseling after the cessation of the flood. The content is presented in the article aims to contribute to the deepening of knowledge about the flood and how to deal with its consequences, but also present information on effective measures to be taken to minimize the loss of people who experienced this disaster.

According to the findings of researchers dealing with disasters (Kaniasty, Noris, 1995) the support period after the disaster should be limited in time to the situation of the occurrence of hazards and immediately interrupted for people who are able to undertake activities to improve the situation in which they find themselves. It is important to create the social conditions for the adoption of measures to minimize the effects of the disaster. Otherwise, the aid received from public institutions and NGOs instead of becoming a social support will be a factor disintegrating communities and the same unit, which experienced flooding. In the literature, rarely take the thread support victims of social assistance centers, more fundraiser is paid to the occurrence of psychological and health consequences of various types of disasters, accidents or traumatic events. In 2002, in the journal Psychiatry has made the most extensive review of the research literature concerning traumatic events related to, among others, floods (Norris, F.H et al 2002). The Polish sociological literature publications are mainly for organizing local communities in the context of flooding. Wojciech Sitek (1997) describes organizing local communities in Wroclaw during the flood in 1997, Krzysztof Frysztacki and Teresa Sołdra-Gwiżdż (1999) describe the course and consequences of floods in Opole in 1997, Christopher Kaniasty (2003) describes the psychosocial consequence of the floods in 1997 . Violetta Knapik $(2013,2014)$ analyzes the impact of flooding on the 
community life of rural residents. Wojciech Biernacki and his team (2009) conducted a study on the perceptions and knowledge about natural hazards and the sense of disaster risk in communities (Biernacki, Bokwa, Działek, Padło 2009). In the context of the support by the welfare institutions should indicate a report prepared by the Regional Social Welfare Centre in Rzeszów (Zajdel-Ostrowska, 2013). A study conducted in 2012 among residents of the municipality and city Gorzyce and Tarnobrzeg affected by floods in 1997 and 2010 made it possible to draw conclusions. The positive is that we all asked in the survey confirmed the receipt of a greater or lesser extent, in-kind support material or immaterial as a result of flooding in the study area Tarnobrzeg and municipalities Gorzyce. The most often cited form of support for those affected by the floods was financial assistance (28.3\%), followed by assistance in the form of materials for removing the effects of floods (22.9\%). Respondents indicated that the activities that the greatest should be implemented by government organizations and NGOs should relate to activities aimed at strengthening existing levees (34.4\%). Despite the experience twice the floods, the majority of respondents do not plan to change their place of residence. Such a decision is often associated with a lack of adequate financial resources - selling and buying a new home in a place where there is no risk is not possible, either due to the fact that real estate Flood lost much in value, and that the lack of people willing to purchase them. Another reason to stay in the current place of residence work is performed, attached to the house and the area. Respondents do not think about carrying to another place, because they have health problems and are no longer in the elderly.

\section{Methods}

The project was carried out in 2013, on a researched sample of 500 people who experienced the impact of floods in 2010. The research material was collected using a questionnaire (containing closed questions, semi-open and open) and in-depth interviews. The problem of the study was a description of flooding, ie, among others, difficulties associated with the occurrence of the disaster, the description of the victims survive, the aid received, the assessment of aid and institutions providing aid, expectations of donors.

External research company conducted a study on a target sample of individuals that are referred to as " heads of families ". Examined 500 people who have experienced the effects in the context of disaster - a questionnaire survey. Purposeful selection of people from the area municipalities most affected by the flooding, i.e. rural municipalities: Szczurowa (Małopolskie), Wilków (Lubelskie) and Cisek (Opole), and the municipalities of Sandomierz (Świetokrzyskie), Jasło (Podkarpackie), and urban - rural areas such as Bogatynia (Dolny Śląsk). Gminy na terenie których przeprowadzono badania zostały zaliczone do 18 najbardziej poszkodowanych podczas powodzi w 2010 roku.

In addition, individual in-depth interviews were conducted in the areas surveyed municipalities with 25 people who suffered during the disaster and 25 people who provided support (represented by central and local government, social welfare institutions and NGOs). There were conducted an average of 4 interviews with victims and providing support to the individual municipalities.

\section{Analysis}

Public institutions, such as the local council, the city council and social welfare centers during floods and after the resignation of grant aid to victims of various types, depending on the situation of the household and the size of the losses. Respondents in the study using a questionnaire interview were asked to identify which forms of support offered by public institutions using. The most downloaded form of assistance was financial support - in the first stage as a handout for basic needs after the flood - to 6 thousand polish zloty (benefited from it more than $88 \%$ of victims) in the second stage as a means for the renovation or reconstruction of residential building (took advantage of them almost $80 \%$ of victims). More than one third of victims obtained from public institutions as in-kind assistance (38\%) and help remove impurities accumulated as a result of flooding (35.4\%). Every fifth household also received support in the form of colonies for the child / children and $14.3 \%$ - an education allowance. If you do not take into account the households in which selected " not applicable", i.e. those which do not have school-age children, we can conclude that $60 \%$ of households whose members are school-age children, received support in the form of colonies, and $42 \%$ in the form of education allowance. 
Table 1. Scale of use by households affected by the flood with various forms of assistance offered by public institutions (municipal office, social welfare center, government).

\begin{tabular}{|c|l|c|c|c|c|c|}
\hline & & \multirow{2}{*}{ L.p. } & \multicolumn{3}{|c|}{$\begin{array}{c}\text { Does the household have received } \\
\text { assistance in the prescribed form? (\%) }\end{array}$} & \multirow{2}{*}{ Total } \\
& Form of assistance offered by public institutions & & Yes & No & DNA & \\
\hline 1. & Financial assistance to meet the necessities of life to 6000 PLN & 499 & 88,2 & 9,2 & 2,6 & 100,0 \\
\hline 2. & $\begin{array}{l}\text { Financial assistance for the repair or reconstruction of up to 20.000 } \\
\text { PLN, to 100.000 PLN and up to 300000 PLN }\end{array}$ & 493 & 79,5 & 15,2 & 5,3 & 100,0 \\
\hline 3. & $\begin{array}{l}\text { Assistance in materials (eg, Construction materials, home } \\
\text { electronics / appliances, furniture, etc.) }\end{array}$ & 497 & 38,0 & 51,3 & 10,7 & 100,0 \\
\hline 4. & Providing a replacement residence (container) & 498 & 15,3 & 20,9 & 63,9 & 100,0 \\
\hline 5. & $\begin{array}{l}\text { Help (physical) in removing the effects of floods - removing } \\
\text { impurities }\end{array}$ & 495 & 35,4 & 53,1 & 12,5 & 100,0 \\
\hline 6. & Help (physical) reconstruction household & 497 & 11,1 & 62,4 & 26,6 & 100,0 \\
\hline 7. & Support Specialist (psychological., lawyer, family) for flood victims & 495 & 11,7 & 40,0 & 48,3 & 100,0 \\
\hline 8. & Holiday trip for a child & 498 & 19,9 & 13,1 & 67,1 & 100,0 \\
\hline 9. & Education allowance for children & 491 & 14,3 & 19,8 & 66,0 & 100,0 \\
\hline 10. & Support for people with disabilities & 487 & 5,3 & 11,1 & 83,6 & 100,0 \\
\hline 11. & Another type of assistance & 453 & 60,9 & 25,4 & 13,7 & 100,0 \\
\hline
\end{tabular}

It should be noted that until 2010 in Poland there wasn't any rules governing aid to victims of natural disasters, including floods. Legal basis for support of flood victims by the State direct financial assistance under the tasks of government implemented by the municipalities, are the provisions of the Act of 12 March 2004 on social assistance allowance permitting a non-refundable grant targeted person or family who have suffered losses due to natural disaster, regardless of the income of that person or family. However, these provisions beyond the general specifying the circumstances in which and who is entitled to benefits purposeful, do not specify the relevant issues in this case, including the manner and procedure for the determination of the allowance. At the central level by the Ministry of Internal Affairs and Administration has issued detailed guidance on support for victims. The scale of the flood was very large and therefore it was necessary interpretation of the rules and thus describes one of the social workers I mean, yes, I say, there were many specific situations, when you do not really know how to act in a given situation, guided inquiry to the Ministry, received quick answers, so I say, well, there was a problem. We know not, for the answer you need to wait a few days, but it was not an elongated, so I speak in doubtful matters, we asked the Ministry, received such answers, how to deal with specific situations. (Sandomierz, Helper 4). An important aspect is the way the granting of aid, because, as the report describes the Highest Chamber of Control, as in the case of the so-called. Benefits to 6 thousand polish zloty to cover basic needs after a disaster to the matters related to the granting and payment of aid in a larger size (up to 20 thousand., and over 20 thousand. zł) was performed in a different way, not only in different regions of the Polish, but also within the same municipality . Thus describe social workers should receive assistance: Well, as I say. Over to the other moments the only article that applied to the granting of aid was article 40 of the Law on Social Assistance, which is so vague that it really does not explain you know the same, so to speak the same volume of aid and forms of assistance. It is said only there for the benefit intentional and that in such a situation may be granted and really that's all. Here were a tool guidelines of the Ministry of Internal Affairs and Administration, where there were these guidelines in several letters as it turned out wanting to rely on these guidelines, each claimed that it is not a legal obligation. Yes claimed local government appeals board, so the courts took the view, that really knows you legally cannot have it buttoned up. What else these allowances for farmers affected by the floods there was a regulation that describes who is eligible for this form of assistance, how much they need to meet the conditions and little of that for when I need to submit an application to have been considered and what happens to the administration of the complex time. So that is without consideration, it was probably a short twoor three-page regulation but not clearly shows, when it comes to benefits is targeted social assistance to repair homes and to support the current priority needs not here, unfortunately, there was no strict rules. (Wilków, Helper 3).

Representatives of households affected by the flood, who were invited to participate in the study, evaluated the extent to which public institutions receive support from their expectations fulfilled. The results show that the highest level of satisfaction of the expectations of the victims appeared in the case of support offered to children - in the form of education allowance and colonial trips (less than 12\% of declarations with a low degree of satisfaction, over $67 \%$ of large). High level meet expectations was also reported in relation to provide a replacement residence (42.1\% - a rather large and 35.5\% - very large) and for help in removing the effects of floods (filth) - help has fulfilled the expectations of the 
third victim degree rather large and at the third in a very large extent. Financial support (grant to 6 thousand. Dollars and support for the renovation / reconstruction) as well as in-kind support to the expectations of victims responded to a much lesser extent. Aid for basic needs after the flood, fulfilled the expectations of $25 \%$ of the victims of degree rather small, and almost $14 \%$ in a very small extent. With regard to support for the renovation / restoration of the highest percentage of victims declared a rather large degree of satisfaction of expectations (33.2\%), but $27 \%$ found them to be rather small, and a further $11.7 \%$ for very small. Material help was assessed with the same frequency as meeting the expectations of the degree rather small and rather large, but among the strong dominant negative $(18.5 \%$ - a very small degree of satisfaction of the needs and $14.3 \%$ - very large). Presents an interesting assessment of the distribution of the degree of satisfaction of expectations relating to support for people with disabilities, whereby we must remember that this aspect was evaluated by a small group of respondents ( 26 people). Answers " rather small " and " rather large " and " very small " and "very high " were selected with exactly the same frequencies.

Victims who have benefited from any form of support from the social welfare center, were asked to rate various aspects of the functioning of the institution relating to the provision of assistance after the flood. Respondents evaluated the effect of social assistance center with its own area municipalities by granting from 1 to 5 points, where 1 is the strongly negative and strongly positive assessment 5.

Top rated aspects of social welfare centers is the timely delivery of financial services (3.89 pts.), The rate of support after the falling water ( $3.79 \mathrm{pts}$.) And the availability of workers welfare centers (3.74 pts.). By far the lowest rated granted specialist support needed (eg, psychological, legal - 3.12 pts.), As well as information about available forms of assistance ( $3.30 \mathrm{pts}$.) And the amount of financial support paid by these institutions. All aspects were rated between 3.10 and 3.90 points, so better than average and less than well - it is difficult to speak of a large variety of evaluations of specific aspects. Differentiation is seen while in the individual municipalities. In the municipality of Jaslo until four aspects of the social welfare center has been assessed at least good (above $4.00 \mathrm{pts}$.) And it should be emphasized that in any of the other municipalities not reported any grade point average at 4.00 points. Such a positive assessment related to the treatment of victims by the social workers, the timeliness of payments, availability of staff and speed of support. In the municipality of Wolves, however, only the speed and timeliness of payments support is the only among the 11 aspects, rated at a level higher than 3.50 points. The lowest average ratings (ie 2.10 points). Noted in the evaluation of specialized legal and psychological support offered by the resort social assistance Szczurowa.

Level of satisfaction with the resulting financial assistance for basic needs (handout to $6.000 \mathrm{PLN}$ ) is varied in different municipalities, the it should be noted that this relationship is of moderate strength $(p=0.000, C=0.346)$. Victims of the municipality Bogatynia assessed level of satisfaction of expectations for this form of aid as very high (41.8\%), while in the municipality of Szczurowa this evaluation has not formulated any of the respondents. In the municipality of Wolves over $1 / 4$ of victims considered that the grant to a very small extent, satisfied their expectations, and the fifth, assessed the degree as rather small. Opinions about rather little to meet the needs were also among the most frequent victims of municipalities Sandomierz and Cisek (27,5-31,6\%), and the local inhabitants Cisek much less evaluated this help as very few adequate to the expectations ( $3.5 \%$ of responses ).

Table 2. The extent to which financial assistance to meet the necessities of life (up to 6000 PLN), obtained from public institutions (municipal office, social welfare center, government), fulfilled the expectations of people affected by the flooding. [N=440]

\begin{tabular}{|c|c|c|c|c|c|c|c|}
\hline & \multicolumn{6}{|c|}{ Place (w\%) } & \multirow{2}{*}{ Total } \\
\hline & Szczurowa & Jasło & Wilków & Sandomierz & Cisek & Bogatynia & \\
\hline Very small & 15,4 & 12,5 & 26,7 & 14,5 & 3,5 & 4,5 & 13,9 \\
\hline Rather small & 23,1 & 27,5 & 20,8 & 27,5 & 31,6 & 19,4 & 25,0 \\
\hline Hard to say & 30,8 & 15,8 & 12,9 & 20,3 & 28,1 & 9,0 & 17,3 \\
\hline Rather big & 30,8 & 25,8 & 24,8 & 17,4 & 17,5 & 25,4 & 23,4 \\
\hline Very big & 0,0 & 18,3 & 14,9 & 20,3 & 19,3 & 41,8 & 20,5 \\
\hline Total & 100,0 & 100,0 & 100,0 & 100,0 & 100,0 & 100,0 & 100,0 \\
\hline
\end{tabular}

The evaluation of the level of the satisfaction of the expectations of those affected by flooding financial assistance for the renovation / reconstruction offered by public institutions shows no statistically significant relationship with the type of inhabited villages. In all municipalities except Bogatynia opinions of rather high level of satisfaction expectations are the most numerous and much less numerous than the opinion of the rather small degree to meet expectations. In the case of municipalities Bogatynia level of satisfaction with support for the renovation / reconstruction is much higher - 3/4 victims 
defines it as high ( $37 \%$ as a rather large and the same as very large).

In order to better underline the scale of the use of support for households affected during the floods, respondents were asked, with the support of individuals and institutions which benefited in the following dimensions:

1) material support (financial and in kind),

2) support, consisting in providing information on handling matters related to the effects of floods, coping after the flood, inference on granting aid, etc.

3) Support of emotional (amusingly, understanding, hearing).

Material support for the largest percentage of victims (ie 81\%) were obtained from public institutions (office of the municipality / city social welfare center). Second, the declared material support from family (47.5\%), and strangers (42.1\%). In the case of aid in the form of informing, advising how to cope after a flood comparable to the proportion of victims could count on friends and acquaintances, family members and representatives of public institutions (39\% 40.7\%). Emotional support grant mainly family (72.4\%) and friends and friends (63.4\%).

Table 3. The scale of support provided by the cessation of the flood victims, from various people and institutions.

\begin{tabular}{|c|c|c|c|c|c|c|c|c|c|c|c|}
\hline \multirow[t]{2}{*}{ L.p. } & \multirow[t]{2}{*}{ Source } & \multirow[t]{2}{*}{$\mathrm{N}$} & \multicolumn{3}{|c|}{$\begin{array}{l}\text { Does the household have } \\
\text { received material support } \\
\text { (financial or material)? }\end{array}$} & \multicolumn{3}{|c|}{$\begin{array}{l}\text { Does the household have received support regarding } \\
\text { information on how to perform certain tasks or to } \\
\text { settle matters related to coping after the flood? }\end{array}$} & \multicolumn{3}{|c|}{$\begin{array}{l}\text { Does the household } \\
\text { received psychological } \\
\text { support? }\end{array}$} \\
\hline & & & Yes & No & DNA & Yes & No & DNA & Yes & No & DNA \\
\hline 1. & Family & 495 & 47,5 & 35,4 & 17,1 & 39,0 & 36,4 & 24,6 & 72,4 & 16,7 & 10,9 \\
\hline 2. & Friends & 492 & 33,9 & 44,3 & 21,8 & 40,7 & 34,1 & 25,2 & 63,4 & 21,3 & 15,2 \\
\hline 3. & \begin{tabular}{|l|} 
Volonteers, \\
Religious \\
groups \\
\end{tabular} & 483 & 42,1 & 35,5 & 22,4 & 13,7 & 54,7 & 31,7 & 15,5 & 48,7 & 35,8 \\
\hline 4. & \begin{tabular}{|l|} 
Public \\
Institutions
\end{tabular} & 484 & 81,0 & 14,1 & 4,8 & 39,5 & 34,5 & 26,0 & 13,0 & 48,5 & 38,6 \\
\hline
\end{tabular}

Distribution of answers concerning the frequency of obtaining various forms of support from various people and institutions shows that the support of family and friends more often repeated several or many times, when in the case of strangers and public institution it was likely a one-off or was happening only a few times. For example, multiple financial help from family and friends declared that approximately $35 \%$ of victims, in the case of strangers and public institutions less than $11 \%$. Multiple aid consisting in advising and informing declared more than $40 \%$ in relation to family and friends, and less than $20 \%$ in the case of strangers and public institutions.

Opinions on possible victims of fraud in the breakdown of aid have been verified by a request for comment on the assertion "The aid was distributed fairly." The highest percentage of people who disagree with this statement was recorded in the municipality of the Wolves - which confirms the result obtained with a question concerning the comparison of the aid received assistance from others. Confirmation of such a state of opinion may be the report of the Supreme Chamber of Control, which showed irregularities in the allocation of funds (NIK, 2011). When conducting in-depth interviews as residents pointed to irregularities. My expectations. I was hoping that everything will be done so as it should be. So you come from welfare, have three children. It should be said, for example, a member of the family should be 1 thousand and I should get it and not received. I know that the money was and feels cheated by a caregiver or municipality, I do not know what to call it. I know that many people of good will gave money because then they asked me if it was. I do not know what happened to it. Later this second round of flooding because there were two, the first and second wave. Since the first had 6000 and got 500 zł per family member. Where's the rest of the money? A big question mark. I will not be one of the accounted what happened here (Wolves, Victim 4). The greatest belief in the fairness of distribution of support among local inhabitants in need expressed Cisek, in which every fourth victim expressed his conviction that definitely fair distribution of aid, while only $3.5 \%$ chose the answer decidedly negative. A relatively small proportion claiming that the aid was not distributed fairly well reported in the municipality of Jaslo $(9.5 \%$ definitely unfair and $16.1 \%$ rather unfair), while in Szczurowa largest percentage of people expressed the belief that, rather that the allocation of aid was not fair (31\%). $p=0.00, C=0.392$

Victims also responded to the statement that "the aid was in an atmosphere of friendship and camaraderie." In the municipalities of Szczurowa, Jaslo, Sandomierz and Bogatynia largest group of victims rather agreed with this statement. In the commune Cisek more than $30 \%$ of victims strongly disagreed with this statement, and nearly $30 \%$ corresponded to a moderate degree, which is another proof of the fact that the way the distribution of aid is assessed in the municipality 
most of the six surveyed municipalities. In turn, in the municipality of Wolves, only every fourth victim expressed the belief that the aid was divided in an atmosphere of friendly and more than $60 \%$ of the respondents disagreed with this opinion, choosing the answer moderately negative $(31.4 \%)$ or strongly negative $(32.4 \%)$. The relationship between the municipality in which they live and the way respondents assess this aspect of aid is statistically significant and shows the average strength $(p=0.00, C=0.489)$.

Opinion on the fact that the aid was distributed more on the basis of knowledge than the real flood losses expressed almost $60 \%$ of victims from the community Wolves, including more than $30 \%$ strongly agreed with this view. In the municipality of Szczurowa this view confirmed by over $40 \%$ of respondents, but most of them (27.6\%) chose the answer moderate "rather agree". At the same time more than $41 \%$ of the surveyed residents of the municipality argued that rather this is not true. The lowest percentage of victims expressing the view that the aid was distributed according to knowledge, combined with the highest percentage convinced that this is not true - there is in the municipality of Cisek. $p=$ $0.00, C=0.413$

People who suffered in the floods, asked to comment on the claim that "many people have received assistance, though they do not belong" frequently declared lack of knowledge on the subject and chose the answer "do not know". The exception is the municipality Bogatynia, in which up $45.6 \%$ of the respondents strongly agreed with this view, and another $20.6 \%$ said that rather agree with him. A significant proportion of victims who perceive this type of problem (27.6\% in a decisive and $26.5 \%$ moderate) were reported in the municipality of Wilków. ( $p=0.00, C=0.357$ ).

Victims also have the issue of addressing those claims that almost all of them were satisfied with the assistance - a total of $38.2 \%$ of respondents chose the answer "do not know", in the case of municipalities Szczurowa this proportion was as high as $50 \%$. The percentage of victims who do not agree with this statement was higher than the percentage of people agreeing with him, only in the municipalities of Wilków and Sandomierz. $(p=0.00, C=0.375)$.

Respondents could not comment explicitly on the question of whether there was a group of victims, which was omitted by public institutions in the allocation of aid in their municipality. A total of $40.5 \%$ of people abstained from the evaluation of this view. Among the clear answers most frequently pointed to the "rather disagree", and the interest definitely confirming this view and strongly rejecting it were close. The analysis showed no statistically significant correlation between the type of municipality and opinion about the omission of the allocation of aid $(p=0.09, C=0.290)$.

With regard to the claim that the distribution of aid by public institutions more divided than the residents of the municipality merged almost identical percentage of respondents pointed to the answer "rather agree" and "somewhat disagree" (almost 22\%). Among the opinion of the vast strength, however, were far outnumbered those that confirmed this negative fact $(24.3 \%$ strongly agree and $4.2 \%$ strongly disagree). Noteworthy, however, far removed from the average score for the municipality of Wolves, in which only $5 \%$ of victims did not agree with the view that aid for flood victims divided residents and more than $72 \%$ agreed with this view in a decisive manner. $(p=0.00, C=0.577)$

Taking into account the fact that the assessment of the functioning of the centers of social assistance and support provided by not were not very high, the victims were asked to identify whether the lack of some kind of support from the social welfare center, and if so - what support was missing? Deficiencies in the support offered by the centers saw an $15.4 \%$ of respondents, with the scale of this type of declaration is varied in the different municipalities: from $36.7 \%$ in the municipality of Szczurowa, and only $2.5 \%$ in Bogatynia, $(p=0.00, C=0.304)$

Any shortcomings respondents mentioned yourself - in the form of open. Most attention was paid to the lack of interest, understanding, and psychological support. Second, the perceived deficiencies in informing victims - mainly on the possibilities for support. Declared the shortcomings of the amount to be awarded benefits and the lack of support in the cleaning and restoration. Among other deficiencies - exchanged in individual cases - emerged: lack of justice in the chapter support, the lack of organization of work, failure to provide fuel for the winter, the lack of support in kind and too late disbursement of the funds. 
Figure 1. Absence of support provided by social welfare centers after the falling water (mentioned by respondents in the open-ended question).

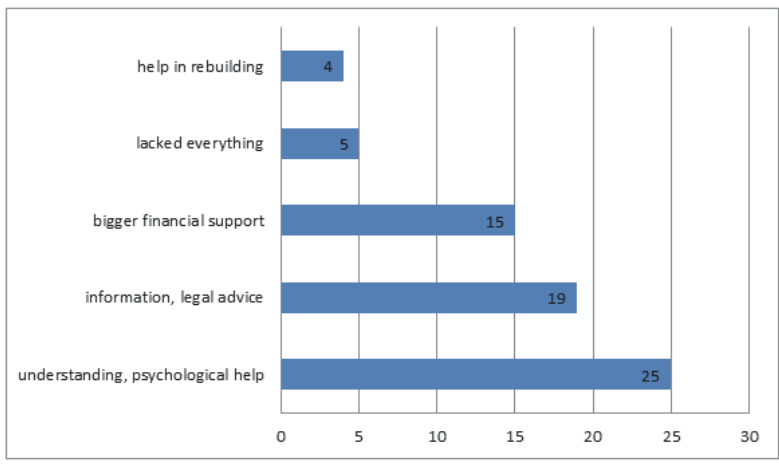

Every fourth representative household that suffered losses during the flood, declared that there are things that should be changed in the functioning of social assistance center to help was more effective. More than $43 \%$ of victims did not see the need to make changes, and others - that is, almost every third respondent - have no opinion on the matter.

\section{Conclusion}

Flooding is an element of a nature, which is very difficult to avoid, you can only try to minimize the damage. In the event of such a severe natural disaster assistance to the government, the local government has proven necessary. The purpose of this publication is to provide information on the situation of the inhabitants of the areas affected by floods in Poland in 2010, both in terms of the support provided by the social services and financial situation , as well as mood and social expectations. The positive is the fact that the majority of those interviewed in the study acknowledged receipt of a greater or lesser extent, in-kind support material or immaterial as a result of flooding. The most often cited form of support for those affected by the floods was financial aid, and aid in the form of materials for removing the effects of floods. Residents of flooded areas are very critical of the procedure for granting aid. " Rigid " settlement dates received funds contributed to the haste in carrying out repair work, which directly resulted in the poor quality of the works. However, timely payment of benefits from the social assistance was the highest rated among the analyzed aspects of aid institutions.

\section{References}

Biernacki, W., Bokwa, A., Działek, J., Padło, T., (2009). Społeczności lokalne wobec zagrożeń przyrodniczych i klęsk żywiołowych, IGiGP UJ, Kraków, http://www.geo.uj.edu.pl/publikacje.php?id=000135\&page=monografie\&lang=1

Frysztacki. K., Sołdra-Gwiżdż. T., (1999), Naturalna katastrofa i społeczne reakcje, Państwowy Instytut Naukowy, Opole, 1-136.

Kaniasty, K. (2003). Klęska żywiołowa czy katastrofa społeczna? Psychologiczne konsekwencje polskiej powodzi 1997 roku. Gdańsk: GWP.

Kaniasty, K., Norris, F. H. (1995). Mobilization and deterioration of social support following natural disasters. Current Directions in Psychological Science, 4, 94-98.

Knapik. W., (2013). Wpływ zagrożenia powodziowego na życie wspólnotowe mieszkańców wsi, Village and Agriculture (Wieś i Rolnictwo), issue: 4 (161),173-189

Knapik. W., (2014), Effects of a flood hazard on social and economic life of rural inhabitants, Acta Scientiarum Polonorum 13 (1), 63-75, http://acta_oeconomia.sggw.pl/pdf/Acta_Oeconomia_13_1_2014.pdf\#page=65

Lerner-Lam, A. (2007). Assessing global exposure to natural hazards: Progress and future trends. Environmental Hazards, 7, 10-19. DOI: 10.1016/j.envhaz.2007.04.007.

Najwyższa Izba Kontroli (2011) Udzielanie pomocy poszkodowanym w wyniku powodzi występujących w 2010 r., Najwyższa Izba Kontroli. 1-56.

Norris F.H., Friedman M.J., Watson. P.J., Byrne. C.M., Diaz, E., Kaniasty. K., (2002) 60,000 disaster victims speak: Part I. An empirical review of the empirical literature, 1981-2001. Psychiatry,3,207-39

Sitek, W., (1997). Wspólnota i zagrożenie. Wrocławianie wobec wielkiej powodzi, Wydawnictwo Uniwersytetu Wrocławskiego, Wrocław 1-111.

Zajdel-Ostrowska. M., (2013). Życie czy przetrwanie analiza sytuacji bytowej mieszkańców miasta Tarnobrzeg oraz gmin Gorzyce województwa podkarpackiego, których dotknęła powódź, Regionalny Ośrodek Pomocy Społecznej w Rzeszowie. 